\title{
Depressed $T$ cell reactivity to recall antigens in Crohn's disease before and after surgical resection
}

\author{
G D’Haens, M Hiele, P Rutgeerts, K Geboes, J L Ceuppens
}

\begin{abstract}
Earlier studies regarding possible primary immune disturbances participating in the pathogenesis of Crohn's disease yielded conflicting results. Peripheral blood lymphocyte subsets and lymphocyte proliferative responses to five soluble recall antigens and to the polyclonal stimulator phythaemagglutinin were therefore measured in 17 patients with active Crohn's disease, before and six months after surgical resection of the inflamed intestine and in 16 healthy controls. Lymphocyte proliferation in response to all five recall antigens was significantly lower in patients than in controls. No significant differences with controls were detected after surgery. Addition of indomethacin to phythaemagglutinin stimulated lymphocyte cultures had a stronger proliferation enhancing effect in patients than in controls, resulting in comparable proliferative responses in both groups. When both indomethacin and prostaglandin $E_{2}$ were added, inhibition of reactivity by prostaglandin $E_{2}$ was stronger in patients' cultures. This suggests a higher sensitivity to inflammatory prostaglandins in Crohn's disease. The degree of lymphocyte stimulation by antigens correlated positively with the percentage of circulating memory $T$ cells (CD $45 \mathrm{RA}^{-}$). The percentage of activated (HLA-DR+) CD8 cells was higher in patients than in controls. The CD4/CD8 ratio, which was not significantly different between patients and controls, correlated significantly with disease activity and characteristics, even in the postoperative phase. These findings suggest that immune abnormalities in Crohn's disease fluctuate with and are probably secondary to inflammatory activity.

(Gut 1994; 35: 1728-1733)
\end{abstract}

Crohn's disease is a chronic inflammatory bowel disease of unknown origin. Hypotheses regarding possible pathogenetic mechanisms include infectious agents such as mycobacteria, autoimmune dysfunction perhaps based on 'molecular mimicry' with bacteria or bacterial products, 'vasculitis', with the endothelial wall as the primary target of the immune attack, permeability disorders of the intestinal mucosa, possibly genetically mediated, and primary immune dysfunctions, especially with regard to immunological suppressor mechanisms. ${ }^{1-4}$
None of these hypotheses have been firmly proved to date. Much more has been shown about the amplification of the inflammatory response involving the arachidonic acid cascade, cytokines such as interleukins and interferons, oxydative radicals, and the complex interaction of various subpopulations of lymphocytes, specifically $\mathrm{T}$ lymphocytes, which seem to orchestrate the destructive inflammatory processes. ${ }^{5-8}$

The increased percentage of $\mathrm{T}_{9}$ antigen bearing circulating lymphocytes ${ }^{9}$ and the increased concentration of circulating interleukin-2 receptor, shed from the surface of activated $T$ cells and macrophages ${ }^{7}$ reflect an increased lymphocyte activation state. Further analysis of the immune response in Crohn's disease showed a generalised defective $\mathrm{K}$ cell and natural killer cell function, which is worse in patients with active disease. ${ }^{10-11}$ The relevance of this to the pathogenesis of Crohn's disease is still unclear.

Earlier studies regarding possible primary immune disturbances entailed in the pathogenesis of Crohn's disease yielded conflicting results. These experiments assessed the immune competence of Crohn's disease patients by measuring reactivity to purified protein derivative (Mantoux tests), ${ }^{12}$ lymphocyte responses to non-specific mitogens such as phytohaemagglutinin, ${ }^{13-15}$ and lymphocyte subsets by means of monoclonal antibodies. ${ }^{16} 17$ Poor nutritional state and different types of immunomodulatory treatments, however, also induce certain changes in the immune function; therefore it is difficult to draw conclusions about primary immune dysfunctions.

In this study we focused on the cellular immune function in active Crohn's disease before and after surgical resection of the inflamed intestinal segments. Disease activity before (clinical score) and six months after (endoscopic score) surgical resection were also determined. This approach would permit us to find out if immunological abnormalities were 'primary', and possibly important in the pathogenesis of the disease, or 'secondary' to the inflammatory processes. We investigated the immune competence by measuring lymphocyte subsets in peripheral blood and by using in vitro lymphocyte proliferation tests in response to five recall antigens, both before and after surgery, and in control subjects. This was combined with measurements of in vitro proliferative responses to phytohaemagglutinin in combination with indomethacin and prostaglandin $\mathrm{E}_{2}$, to clarify the role of prostaglandins released in the inflammatory cascade. 
TABLE I Patients' characteristics

\begin{tabular}{|c|c|c|c|c|c|c|c|c|}
\hline Sex & $\begin{array}{l}\text { Crohn's disease } \\
\text { (bowel segment } \\
\text { affected) }\end{array}$ & $\begin{array}{l}\text { Activity } \\
\text { score }\end{array}$ & Type & $\begin{array}{l}\text { Interval } \\
\text { Dx- } \\
\text { surgery }\end{array}$ & $\begin{array}{l}\text { Indication } \\
\text { for } \\
\text { surgery }\end{array}$ & $\begin{array}{l}\text { Treatment } \\
\text { before } \\
\text { resection }\end{array}$ & $\begin{array}{l}\text { Clinical } \\
\text { recurrence }\end{array}$ & $\begin{array}{l}\text { Endoscopic } \\
\text { recurrence }\end{array}$ \\
\hline $\begin{array}{l}M \\
F \\
M \\
F \\
M \\
F \\
F \\
M \\
M \\
F \\
F \\
M \\
M \\
M \\
M \\
F \\
F\end{array}$ & $\begin{array}{l}\text { TI } \\
\text { TI }+C \\
\text { TI } \\
\text { TI } \\
\text { TI } \\
\text { TI }+C \\
\text { TI } \\
\text { TI+C } \\
\text { TI+C } \\
\text { TI } \\
\text { TI }+C \\
\text { TI } \\
\text { TI }+C \\
\text { TI }+C \\
\text { TI } \\
\text { I } \\
\text { TI }+C\end{array}$ & $\begin{array}{l}\text { A1 } \\
\text { A4 } \\
\text { A2 } \\
\text { A1 } \\
\text { A2 } \\
\text { A3 } \\
\text { A4 } \\
\text { A2 } \\
\text { A3 } \\
\text { A2 } \\
\text { A4 } \\
\text { A0 } \\
\text { A2 } \\
\text { A4 } \\
\text { A2 } \\
\text { A0 } \\
\text { A4 }\end{array}$ & $\begin{array}{l}N P \\
P \\
N P \\
N P \\
P \\
P \\
P \\
P \\
N P \\
N P \\
P \\
N P \\
P \\
P \\
P \\
N P \\
P\end{array}$ & $\begin{array}{l}2 \mathrm{Y} \\
4 \mathrm{Y} \\
4 \mathrm{Y} \\
1 \mathrm{Y} \\
6 \mathrm{Y} \\
2 \mathrm{Y} \\
4 \mathrm{Y} \\
2 \mathrm{Y} \\
10 \mathrm{Y} \\
4 \mathrm{Y} \\
6 \mathrm{M} \\
16 \mathrm{Y} \\
6 \mathrm{Y} \\
13 \mathrm{Y} \\
9 \mathrm{Y} \\
4 \mathrm{Y} \\
6 \mathrm{Y}\end{array}$ & $\begin{array}{l}\mathrm{O} \\
\mathrm{I} \\
\mathrm{O} \\
\mathrm{O} \\
\mathrm{O} \\
\mathrm{O}+\mathrm{A} \\
\mathrm{A} \\
\mathrm{O} \\
\mathrm{I} \\
\mathrm{O} \\
\mathrm{A} \\
\mathrm{O} \\
\mathrm{O}+\mathrm{A} \\
\mathrm{O}+\mathrm{A}+\mathrm{I} \\
\mathrm{O} \\
\mathrm{O} \\
\mathrm{O}\end{array}$ & $\begin{array}{l}S+M \\
S \\
S \\
S+M \\
S \\
5 A S A \\
S \\
S+M \\
\bar{S} \\
M \\
- \\
- \\
S \\
S+M \\
S \\
S\end{array}$ & $\begin{array}{l}\mathbf{N} \\
\mathbf{Y} \\
\mathbf{N} \\
\mathbf{N} \\
\mathbf{N} \\
\mathbf{N} \\
\mathbf{N} \\
\mathbf{N} \\
\mathbf{N} \\
\mathbf{N} \\
\mathbf{N} \\
\mathbf{N} \\
\mathbf{Y} \\
\mathbf{Y} \\
\mathbf{N} \\
\mathbf{N} \\
\mathbf{Y}\end{array}$ & $\begin{array}{l}\text { I2 } \\
\text { I4 } \\
\text { I3 } \\
\text { I3 } \\
\text { I4 } \\
\text { I4 } \\
\text { I2 } \\
\text { I2 } \\
- \\
- \\
\text { I2 } \\
\text { I1 } \\
\text { I0 } \\
\text { I2 } \\
\text { I2 } \\
\text { I1 } \\
\text { I2 }\end{array}$ \\
\hline
\end{tabular}

$\mathrm{TI}=$ terminal ileum, $\mathrm{C}=$ colon. Activity score: $\mathrm{A} 0=$ short or longstanding mild disease, $\mathrm{A} 1=$ active disease (short duration ( $<2$ years), $\mathrm{A} 2=$ longstanding disease with few flare ups, A3 = longstanding disease with frequent flare ups, A4=longstanding disease, continuously active $\mathrm{P}=$ perforating, $\mathrm{NP}=$ non-perforating. Interval $\mathrm{Dx}$-surgery = time interval in years $(\mathrm{Y})$ or months $(M)$ between the initial diagnosis of Crohn's disease and surgical resection. Indication for surgery: $\mathrm{O}=$ obstruction, $\mathrm{I}=$ inflammation, $\mathrm{A}=$ abscess. Treatment: $\mathrm{S}=$ sulphasalazine. ASA = aminosalicylic acid, $M=$ metronidazol. Endoscopic recurrence: $I 0=$ no lesions. $I 1=<5$ aphthous lesions, $\mathrm{I} 2=>5$ aphthous lesions with normal mucosa in between, $\mathrm{I} 3=$ diffuse aphthous ileitis, $I 4=$ diffuse ileitis with large ulcers.

\section{Methods}

PATIENTS AND CONTROLS

Seventeen Crohn's disease patients ( 9 males, 8 females; mean age $33 \cdot 7$, range $22-67$ ) with a firmly established diagnosis of Crohn's disease, based upon endoscopic and histological criteria, were studied (Table I). Patients receiving immune modulatory drugs such as corticosteroids, azathioprine or 6-mercaptopurine were excluded. Most patients were treated with aminosalicylates or sulphasalazine. Disease activity was assessed by means of a clinical score based upon duration and severity of the disease. Peripheral blood was obtained for lymphocyte proliferation and subset determination.

All patients underwent surgical resection of the terminal ileum and caecum with removal of the entire inflamed segment. There was no evidence of Crohn's disease in other parts of the gastrointestinal tract. Twelve of 17 patients $(70.6 \%)$ had surgery because of 'perforating' disease with abscess or fistula formation or with 'perivisceritis' and five of $17(29.4 \%)$ because of 'stricturing' disease with signs of (sub)obstruction.

Endoscopy was performed six months postoperatively to assess recurrent disease, which was present in all but one patient. Four of 17 patients also had clinical recurrence. An 'endoscopic score' was used based on the severity of the observed lesions (Table I). The endoscopists classifying the disease were blinded to the results of all laboratory tests. Blood samples were taken again for the same set of immunological tests. In addition, peripheral blood was obtained from 16 control subjects ( 8 males, 8 females; mean age 32.8, range 25-45). These were employees of the gastrointestinal endoscopy unit, were not taking any drugs, and were considered healthy.

LYMPHOCYTE SUBSET DETERMINATION

Fluorescein or phytoerythrin conjugated monoclonal antibodies (mAb) were purchased from Becton-Dickinson (Mountain View, $\mathrm{CA}$ ). Combinations of mAbs were selected to determine the following lymphocyte subsets: CD19+ and CD20 + B cells; CD3 + total T cells; CD4 + helper/inducer cells; CD8 + suppressor/cytotoxic cells; CD45RA + virgin CD4 cells and CD45RA - memory CD4 cells; HLA-DR+ (activated) CD4 cells; HLA-DR+ (activated) CD8 cells. Monocytes were enumerated by immunofluorescence with phytoerythrin anti-CD14. Fifty microlitres of heparinised blood was incubated with an appropriate dilution of an fluorescein and a phytoerythrin conjugated $\mathrm{mAb}$ at $4^{\circ} \mathrm{C}$. After haemolysis of erythrocytes (twice repeated addition of $\mathrm{NH}_{4} \mathrm{Cl}, \mathrm{pH}=7 \cdot 3$ ), cells were washed twice in phosphate buffered saline and resuspended in $1 \mathrm{ml}$ of $1 \%$ paraformaldehyde.

Two colour immunofluorescence analysis was carried out on a Becton-Dickinson FACS scan flow cytometer. Lymphocytes were gated on the basis of forward and $90^{\circ}$ light scatter.

In each analysis 2000-5000 lymphocytes were counted. Cells were scored positive or negative according to their fluorescence with reference to that of control samples, incubated with fluorescein and phytoerythrin conjugated mouse IgG. The number of positive cells was expressed as percentage of the total lymphocyte count.

\section{ISOLATION OF PERIPHERAL BLOOD} MONONUCLEAR CELLS

Peripheral blood mononuclear cells were isolated from heparinised blood on FicollHypaque (density 1.077) gradients (Pharmacia, Uppsala, Sweden). After three washings in Hanks's balanced salt solution, the cells were resuspended in culture medium: RPMI 1640 (Gibco, Paisley, Scotland) supplemented with $2 \mathrm{mM}$ L-glutamine, penicillin $(100 \mathrm{U} / \mathrm{ml})$, streptomycin (100 microg/ml), and 5\% normal human serum.

IN VITRO STIMULATION OF PERIPHERAL BLOOD MONONUCLEAR CELLS WITH ANTIGENS AND THE MITOGEN PHYTHAEMAGGLUTININ Cells $\left(1 \times 10^{5}\right)$ were cultured in 96 well round bottomed plates (Costar Europe, Badhoevedorp, The Netherlands) with a variety of soluble antigens: streptokinasestreptodornase (streptococcal antigen, 100 $\mathrm{IU} / \mathrm{ml}$ final concentration, Lederle, Belgium), cytomegalovirus $\quad(0.05 \mathrm{IU} / \mathrm{ml}$, Boehring Hoechst, Belgium), herpes simplex virus (0.015 IU/ml, Boehring Hoechst, Belgium), tetanus toxoid $(0.5 \mathrm{LFU} / \mathrm{ml}$, Wyeth, USA), and Candida albicans $(100 \mu \mathrm{g} / \mathrm{ml}$, Haarlem allergenen laboratorium, The Netherlands), and also in the presence of the mitogen phytohaemaglutinin $(0.12,0.25$, and $0.50 \mu \mathrm{g} / \mathrm{ml}$, Wellcome Research, Tuckahoe, NY) and control medium. To block prostaglandin synthesis by the cyclooxygenase arm of the arachidonic acid cascade, we added 

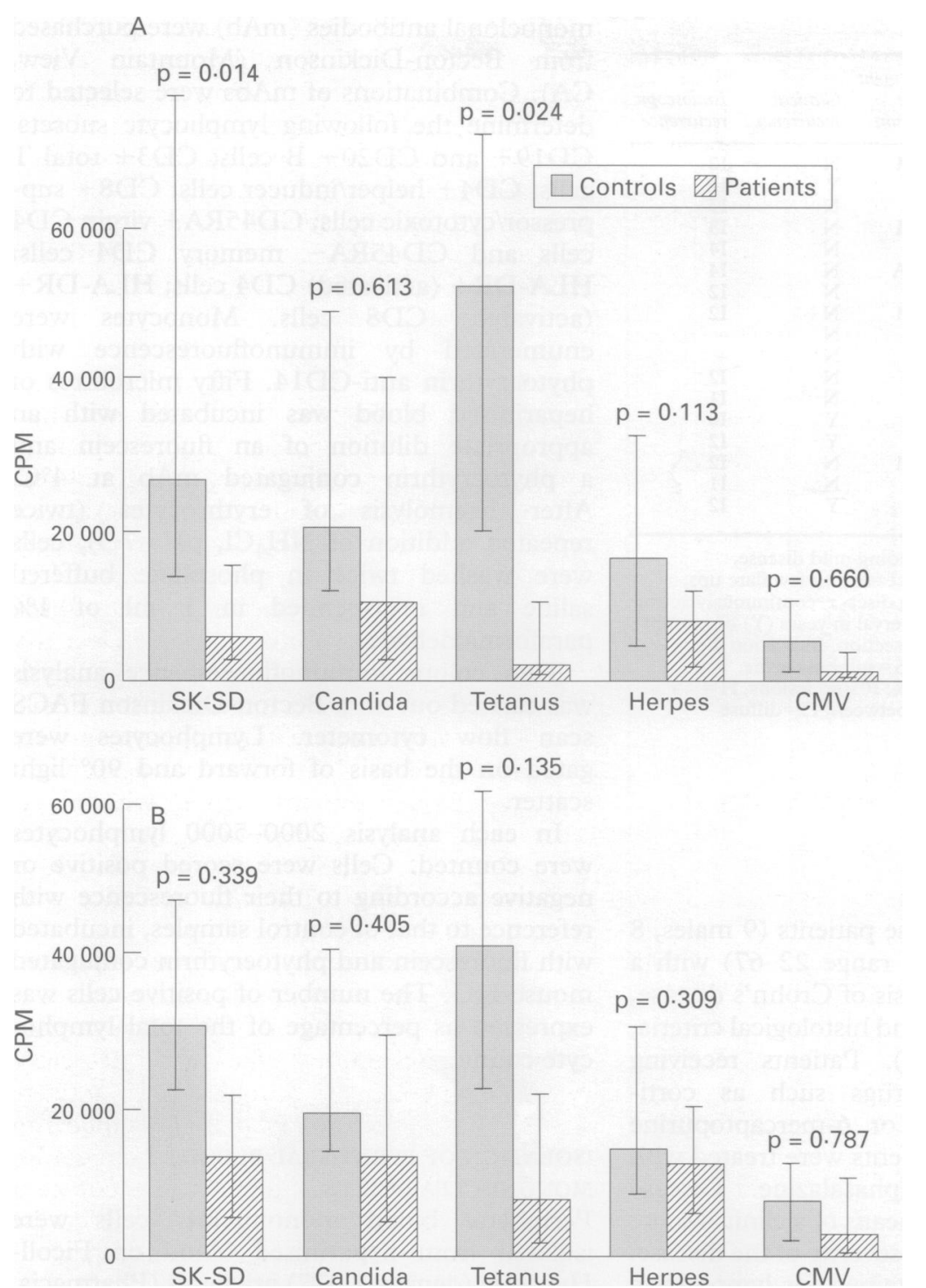

Figure 1: Lymphocyte proliferative responses to recall antigens before $(A)$ and after $(B)$ resection (median, 25th, and 75 th percentile), measured by $\left[{ }^{3} \mathrm{H}\right.$-thymidine] incorporation in lymphocyte cultures and expressed in CPM (counts per minute). Comparison between patients and controls: $p$ values for Wilcoxon two sample test. SK-SD: streptokinasestreptodornase, streptococcal antigen.

\section{Results}

\section{LYMPHOCYTE REACTIVITY TO ANTIGENS AND} MITOGENS

Preoperatively, the proliferative response to the two bacterial antigens streptokinasestreptodornase $(p=0.014)$ and tetanus toxoid $(p=0.024)$ and to three different concentrations of phythaemagglutinin $(p=0.007,0.008$, and 0.019 respectively) was significantly lower in patients with active Crohn's disease than in controls (Figs 1 and 2). Responses to the viral (CMV and herpes) and the fungal (candida) recall antigens were lower in patients than in controls, but this difference was not statistically significant. Within the patient group, there was a correlation between disease activity and reactivity to candida $(p=0 \cdot 02)$. Reactivity to the other recall antigens or to phythaemagglutinin did not correlate with disease activity. No differences in lymphocytic reactivity were noted between patients with perforating or non-perforating Crohn's disease.

Six months after surgery, all proliferative responses were still somewhat lower in patients than in controls, but the difference did not reach statistical significance. No correlation
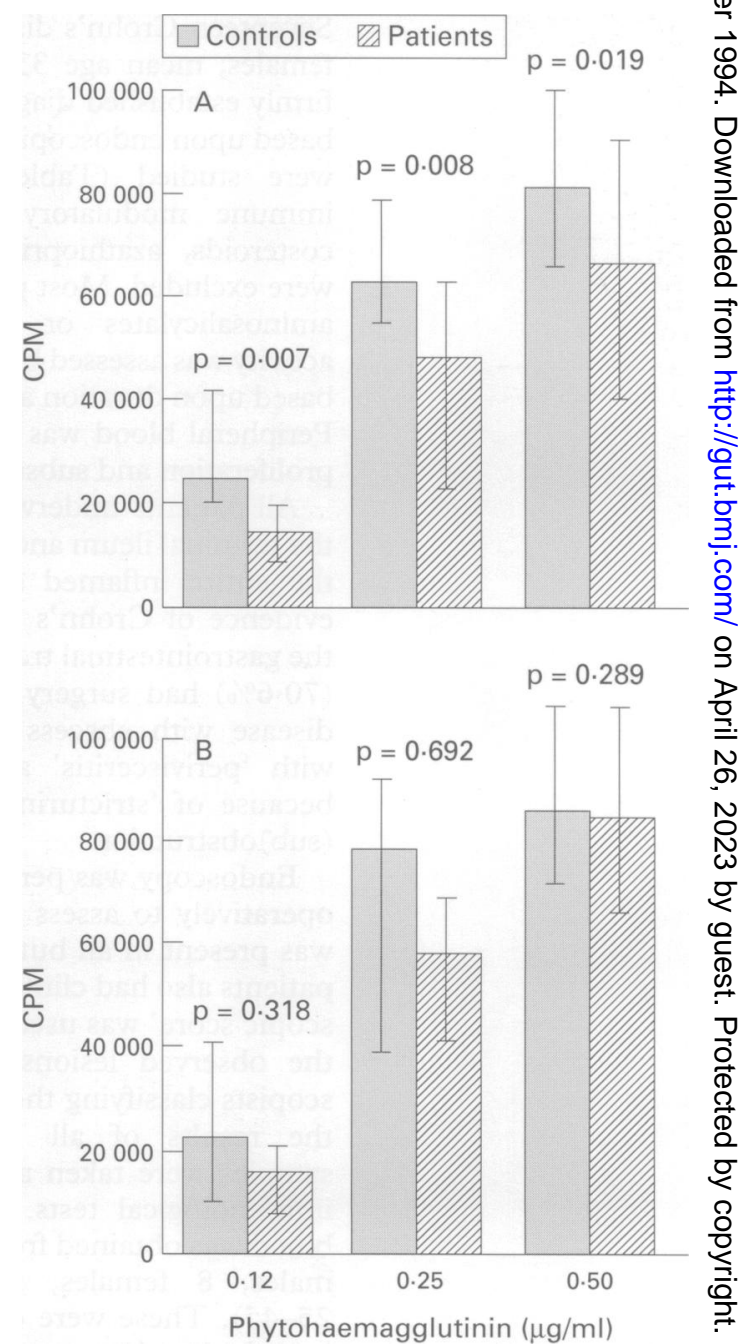

Figure 2: Lymphocyte proliferative response before $(A)$ and after $(B)$ resection to phythaemagglutinin $0 \cdot 12,0.25$, and $0.50 \mu \mathrm{g} / \mathrm{ml}$ (median, 25th, and 75th percentile), measured by ${ }^{3} H$-thymidine] incorporation in lymphocyte cultures and expressed in CPM (counts per minute). Comparison between patients and controls: $p$ values from Wilcoxon two sample test. 


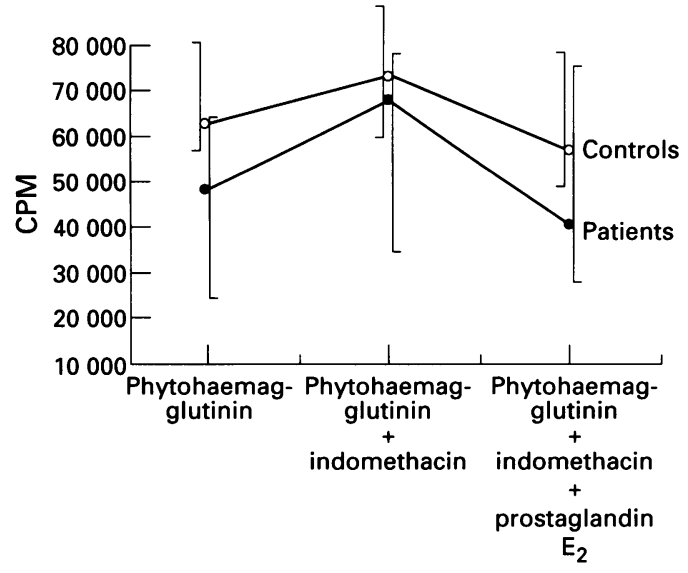

Figure 3: Effect of adding indomethacin $1 \mu \mathrm{g} / \mathrm{ml}$ and indomethacin $1 \mu \mathrm{g} / \mathrm{ml}+$ prostaglandin $E_{2} 3 \cdot 10^{-8} \mathrm{M}$ to phythaemagglutinin $0.25 \mu \mathrm{g} / \mathrm{ml}$ stimulated lymphocyte cultures, measured by [ ${ }^{3} \mathrm{H}$-thymidine] incorporation, expressed in CPM (counts per minute) (median, 25th, and 75 th percentile). Lymphocytes were obtained from patients with active Crohn's disease - that is, preoperatively - and from controls.

TABLE II Lymphocyte subsets in Crohn's disease patients before and after surgery and in controls (mean and range)

\begin{tabular}{|c|c|c|c|}
\hline & Patients & Controls & $p$ Value \\
\hline \multicolumn{4}{|l|}{ Before resection } \\
\hline CD 4 total & $47 \cdot 73(28-71)$ & $50 \cdot 00(37-61)$ & 0.516 \\
\hline CD 8 total & $31 \cdot 31(16-51)$ & $27 \cdot 74(13-43)$ & 0.229 \\
\hline $\mathrm{CD} 4 / \mathrm{CD} 8$ & $1.78(0.59-4.44)$ & $2.05(0.88-4.38)$ & 0.422 \\
\hline HLA DR ${ }^{+} \mathrm{T} 4$ & $2 \cdot 41(0-6)$ & $183(1-4)$ & 0.326 \\
\hline HLA DR ${ }^{+} \mathrm{T} 8$ & $4 \cdot 41(0-18)$ & $1.67(0-3)$ & 0.028 \\
\hline Memory cells & $37 \cdot 16(11-71)$ & $37 \cdot 32(18-61)$ & 0.976 \\
\hline \multicolumn{4}{|l|}{ After resection } \\
\hline CD 4 total & $44 \cdot 63(30-61)$ & $47 \cdot 79(33-63)$ & $0 \cdot 230$ \\
\hline CD 8 total & $33.84(22-55)$ & $30 \cdot 68(17-44)$ & $0 \cdot 222$ \\
\hline $\mathrm{CD} 4 / \mathrm{CD} 8$ & $1.43(0.62-2.77)$ & $1.69(0.75-3.71)$ & $0 \cdot 215$ \\
\hline HLA DR ${ }^{+} \mathrm{T} 4$ & $3.00(0-10)$ & $2 \cdot 00(1-4)$ & $0 \cdot 148$ \\
\hline HLA DR ${ }^{+}$T8 & $3 \cdot 37(0-11)$ & $2 \cdot 00(0-5)$ & $0 \cdot 121$ \\
\hline Memory cells & $29 \cdot 16(15-53)$ & $30 \cdot 89(21-63)$ & 0.614 \\
\hline
\end{tabular}

p Values show differences between patients and controls, calculated with the Student's $t$ test.

could be detected between the endoscopic recurrence score and the level of lymphocyte reactivity.

\section{EFFECT OF INDOMETHACIN AND}

PROSTAGLANDIN E 2 ON LYMPHOCYTIC

REACTIVITY

The low proliferative responses to phythaemagglutinin were further explored by studying the effect of indomethacin and of prostaglandin $\mathrm{E}_{2}$ (Fig 3). Indomethacin, which blocks monocyte prostaglandin production, restored phythaemagglutinin induced proliferation of patients' lymphocytes to almost normal values. After adding prostaglandin $\mathrm{E}_{2}$ to the cultures already containing indomethacin, phythaemagglutinin induced proliferative responses in patients' cultures were more strongly suppressed than in controls, suggesting an increased lymphocytic sensitivity to prostaglandin $\mathrm{E}_{2}$ in Crohn's disease.

\section{LYMPHOCYTE SUBSETS}

Analysis of lymphocyte subsets did not show any significant differences between patients and controls except for the percentages of activated CD8 (HLA $\mathrm{DR}^{+}$) suppressor/cytotoxic cells, which were clearly higher in patients before $(p=0.028)$, but not after $(p=0 \cdot 121)$ surgery (Table II). Furthermore, when subsets of patients were analysed, it became clear that the CD4/CD8 ratio, which was not significantly different between patients and controls, correlated with both clinical (preoperatively, $\mathrm{p}=0.01$ ) and endoscopic (postoperatively, $\mathrm{p}=0.04$ ) disease activity scores, with higher ratios in patients with perforating than in those with non-perforating disease (Fig 4). Other lymphocyte subsets did not correlate with disease activity or characteristics.

Correlations were analysed between lymphocyte subsets and proliferative responses to antigens and phythaemagglutinin to find possible explanations for the decreased lymphocyte reactivity. Stimulation by antigens in Crohn's disease patients significantly correlated with the percentage of circulating memory cells $(p=0.02)$ : a higher percentage of memory cells resulted in stronger proliferative responses to the five recall antigens (Fig 5).

\section{Discussion}

Our results clearly showed that Crohn's disease patients before surgery had significantly lower lymphocytic reactivity, when measured by means of proliferative responses to recall antigens and phythaemagglutinin, than matched control subjects. This decreased reactivity disappeared after surgical resection, although a slight, not significant difference between patients and controls persisted. The finding that the immune abnormalities are more pronounced in patients having an active

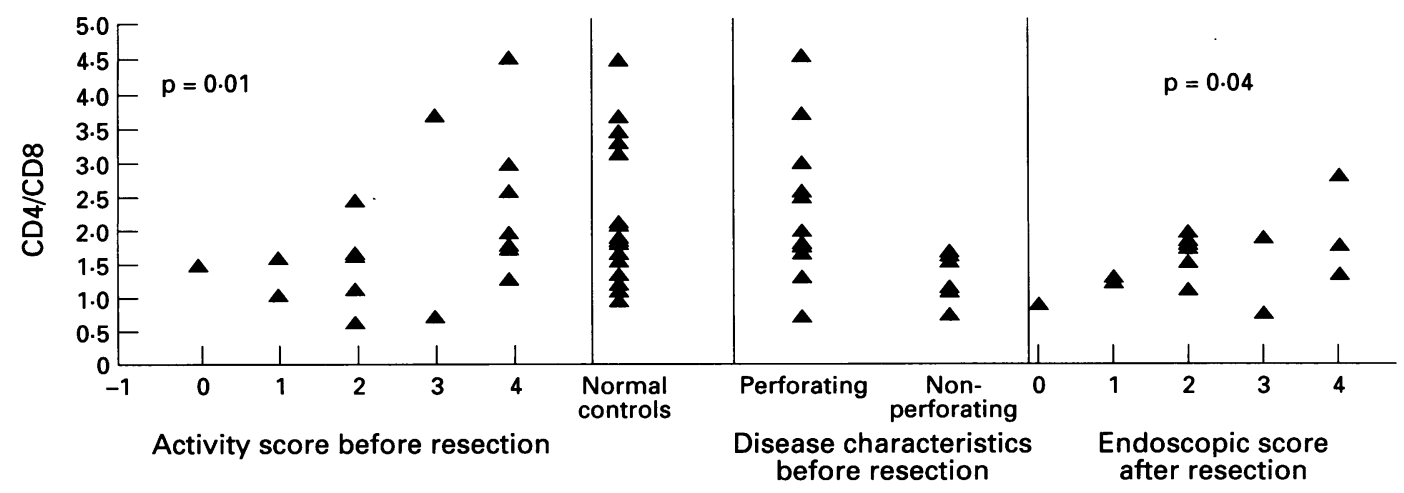

Figure 4: Correlation between disease activity score, disease characteristics, and endoscopic recurrence score (see Table I for definitions) and CD4/CD8 ratio. p Values calculated with Spearman rank test. 


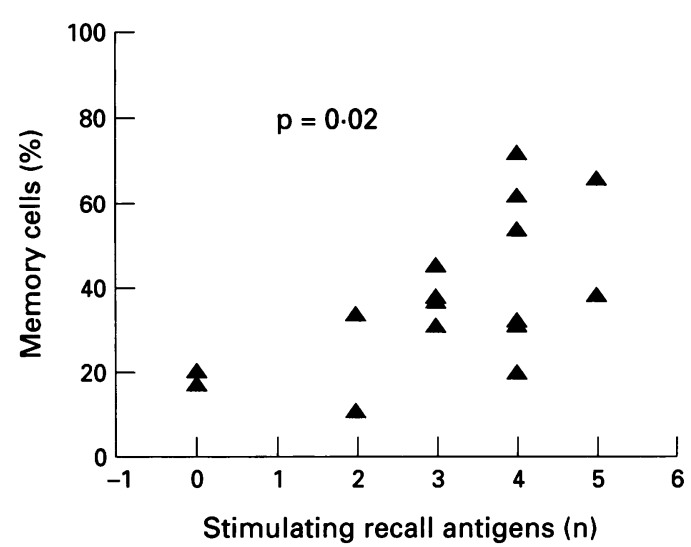

Figure 5: Scatterplot of circulating memory cells (\%) v 'antigenic reactivity' in Crohn's disease patients, expressed as the number of antigens (out of five) in response to which mean $\left[{ }^{3} H\right.$-thymidine] incorporation was higher than the cut off value. (Spearman rank, $p=0.002$.)

form of Crohn's disease suggests that they are probably secondary to and fluctuate with the general inflammatory activity. It would indeed be expected that 'primary' immune dysfunctions persist independently of the actual activity of the disease. The persisting though non-significant differences between patients in the postoperative phase and controls could be explained by the presence of recurrent Crohn's disease in all but one patient, as it was discovered by routine endoscopic and histological examinations.

We tried to explain the diminished immune competence in Crohn's disease patients by measuring lymphocyte subsets. The most significant finding regarding the subsets was that the proportion of activated suppressor/ cytotoxic CD8 cells (CD8 HLA DR ${ }^{+}$) was higher in patients than in controls, which may be one clue to explain the altered immune reactivity. ${ }^{18}$ This activation of peripheral blood and also of intestinal lamina propria lymphocytes was shown before by Pallone et $a{ }^{19}$ as was an enhanced $T$ cell cytotoxicity in the peripheral blood from inflammatory bowel disease patients. ${ }^{20}$ Despite endoscopically proved recurrence six months after surgical resection, the proportion of activated $\mathrm{CD} 8$ cells was not significantly higher in patients than in controls, probably because of low disease activity. The CD4/CD8 ratio was not significantly different between patients and controls, but correlated with the disease activity and was higher in patients with perforating Crohn's disease, reflecting an imbalance between helper/inducer and suppressor/cytotoxic cells in subjects with active inflammation. CD4/CD8 ratios also correlated with the severity of endoscopically confirmed recurrence, suggesting that this ratio is a very sensitive parameter in the early stages of inflammatory activity.

In our study we measured the CD45 RA (memory) CD4 lymphocytes, which have the ability to proliferate vigorously when stimulated by antigens to which the donor has been primed in vivo (so called 'recall' antigens). ${ }^{21}$ There was no difference in size of this subgroup between patients and controls, but within the patient group a correlation was found between lymphocyte reactivity to the recall antigens and the number of circulating memory cells. This could well be a result of the inflammatory processes in the gut, where memory cells are pooled in sites of disease activity, and partly return into the peripheral blood.

Lymphocyte reactivity to phythaemagglutinin in different concentrations has been determined in a number of previous experiments, but significant differences between patients and controls were not systematically detected. 141522 Our experiments, however, clearly show a decreased proliferative response to phythaemagglutinin in Crohn's disease patients when compared with controls. These differences between patients and controls were no longer significant after surgical resection. When indomethacin, a potent inhibitor of prostaglandin synthesis by the cyclooxygenase pathway, ${ }^{23}$ was added to the $0.25 \mu \mathrm{g} / \mathrm{ml}$ phythaemagglutinin stimulated cultures, a stronger impact (growth stimulation) was noted in cultures from patients compared with the controls, so that patients' cultures, in the presence of indomethacin, did not in fact proliferate differently from controls. Inhibition of proliferation by adding prostaglandin $\mathrm{E}_{2}$ in the next step, was again stronger in patients than in controls. All this suggests a higher sensitivity of patients' lymphocyte cultures to prostaglandins. There may also have been a higher activity of prostaglandin producing suppressor cells in cultures from Crohn's disease patients, but prostaglandin production was not routinely measured in our study. It indeed has been shown extensively that intestinal inflammation is accompanied by an increased prostaglandin production, which can be measured in stool, venous blood, and rectal mucosa, ${ }^{24} 25$ and it was suggested that the decreased lymphocyte responsiveness may be explained by it. ${ }^{26}$

The lower CD4/CD8 ratio in non-perforating Crohn's disease corresponds with findings in fibrosing forms of rheumatoid arthritis. ${ }^{27}$ The immunological analogy between Crohn's disease and rheumatoid arthritis is striking. Not only is there a distinct correlation between the activity of the synovial inflammation and both the CD4/CD8 ratio and lymphocyte proliferation in response to recall antigens, but these responses correlate with the percentage of circulating memory cells as well. ${ }^{28}$ Similar to Crohn's disease, circulating memory cells are pooled in the inflamed tissues (synovia) in rheumatoid arthritis. ${ }^{29} 30$

The most recent data regarding the immunological events in Crohn's disease focus upon the intestinal lymphocyte compartment. An enhanced state of intestinal $B$ and $T$ lymphocyte activation has been shown in a growing number of experiments. ${ }^{31} 32$ Most intestinal lymphocytes seem to be Leu-8-, $\mathrm{CD}_{4}+$ and functionally enhance $\mathrm{B}$ cell activation. ${ }^{33} 34$ There may seem to be a paradox between the highly active state of intestinal lymphocytes and the defective proliferative response of peripheral blood lymphocytes to recall antigens and phythaemagglutinin. It is

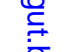


probable, however, that part of the immune activation of lymphocytes takes place after their entry into the intestinal compartment. ${ }^{1935}$ Some (but apparently not all) particular activated subpopulations, however, could migrate back into the systemic compartment. The diminished immune competence of circulating lymphocytes could therefore be caused by the loss of certain groups of immune competent lymphocytes to the intestinal tissues. Future research will further resolve this puzzling relation between peripheral blood and intestinal wall immunology.

1 Chiodini RJ. Crohn's disease and the mycobacterioses. A review of comparison of two disease entities. Clin Microb Rev 1990; 2: 90-117.

2 Wakefield AJ, Sankey EA, Dhillon AP, Sawyerr AM, More L, Siñ R, et al. Granulomatous vasculitis in Crohn's disease. Gastroenterology 1991; 100: 1279-87.

3 Hollander D. Crohn's disease: a permeability disorder of the gastrointestinal tight junction? Gut 1988; 29: 1621-4.

4 MacDermott RP, Stenson WF. Alterations of the immune system in ulcerative colitis and Crohn's disease. $A d v$ system in ulcerative colitis
Immunol 1988; 42: 285-328.

5 Peskar BM. Inflammatory mediators in inflammatory bowel disease. Can 7 Gastroenterol 1990; 4: 289-94.

6 Vane JR. Prostaglandins as mediators of inflammation. $A d v$ Prostaglandin Thromboxane Res 1976; 2: 791-801.

7 Mueller C, Knoflach P, Zielinski CC. T-cell activation in Crohn's disease. Increased levels of soluble interleukin-2 receptor in serum and supernatants of stimulated peripheral blood mononuclear cells. Gastroenterology 1990 98: 639-46.

8 Grisham MB, McCord JM. Chemistry and cytotoxicity of reactive oxygen metabolites. In: Taylor AE, Matalon $\mathrm{S}$, Word $\mathrm{P}$, eds. Physiology of oxygen radicals. Bethesda: American Physiological Society, 1986: 1-18.

9 Raedler A, Fraenkel S, Klose G, Seyfarth K, Thiele HG. Involvement of the immune system in the pathogenesis of Crohn's disease. Expression of the $T_{9}$ antigen on peripheral immunocytes correlates with the severity of the disease. Gastroenterology 1985; 88: 978-83.

10 Auer IO, Ziemer E. Immune status in Crohn's disease IV. In vitro antibody dependent cell-mediated cytotoxicity in peripheral blood. Klin Wochensch 1980; 58: 779-87.

11 Auer IO, Ziemer E, Sommer H. Immune status in Crohn's disease: decreased in vitro natural killer cell activity in peripheral blood. Clin Exp Immunol 1980; 42: 41-9.

12 Williams WJ. A study of Crohn's syndrome using tissue extracts and the Kveim and Mantoux tests. Gut 1965; 6: 503-5.

13 Brown SM, Taub RN, Present DH, Janowitz HD. Shortterm lymphocyte cultures in regional enteritis. Lancet 1970; i: 1112 .

14 McHattie J, Magil A, Jeejeebhoy K, Falk RE. Immunoresponsiveness of lymphocytes from patients with Immunoresponsiveness of lymphocytes from patients with Clin Res 1971; 19: 779.

15 Bolton PM, James SL, Newcombe RG, Whitehead RH, Hughes LE. The immune competence of patients with inflammatory bowel disease. gut 1974; 15: 213-9.

16 Selby WS, Jewell DP. T lymphocyte subsets in inflammatory bowel disease: peripheral blood. Gut 1983; 24: 99-105.
17 Yuan SZ, Hanauer SB, Kluskens LF, Kraft SC. Circulating lymphocyte subpopulations in Crohn's disease. Gastroenterology 1983; 85: 1313-8.

18 Yu DT, Winchester RJ, Fu SM, Gibofsky HS, Ko HS, Kuntel HG. Peripheral blood Ia-positive T cells. $f$ Exp Med 1980; 151: 91-100.

19 Pallone F, Fais S, Squarcia O, Biancone L, Pozzilli P, Boirivant $M$. Activation of peripheral blood and intestina lamina propria lymphocytes in Crohn's disease. In vivo state of activation and in vitro response to stimulation as defined by the expression of early activation antigens. $G u t$ 1987; 28: 745-53.

20 Shanahan F, Brogan M, Targan S. Enhanced periphera blood cytotoxicity in inflammatory bowel disease. $\mathcal{F}$ Clin Immunol 1989; 9: 55-64.

21 Sanders ME, Makgoba MW, Shaw S. Human naive and memory $T$ cells: reinterpretation of helper-inducer and suppressor-inducer subsets. Immunol Today 1988; 9. suppressor

22 Bird AG, Britton S. No evidence for decreased lymphocyte reactivity in Crohn's disease. Gastroenterology 1974; 67: reactivity

23 Goodwin JS, Ceuppens J. Regulation of the immune response by prostaglandins. F Clin Immunol 1983; 3: 295-315.

24 Gould SR. Assay of prostaglanin-like substances in faeces and their measurement in ulcerative colitis. Prostaglandins 1976; 11: 489-97.

25 Gould SR, Brash AR, Conolly ME. Increased prostaglandin production in ulcerative colitis. Lancet 1977; ii: 98.

26 Victorino RMM. Indomethacin sensitive suppressor cells in Crohn's disease: a possible role in decreased lymphocyte responsiveness. F Clin Lab Immunol 1983; 11: 197201 .

27 Haraoui B, Wilder RL, Malone DG, Allen JB, Katona IM Wahl SM. Immune function in severe, active rheumatoid arthritis: a relationship between peripheral blood mononuclear cell proliferation to soluble antigens and mononuclear cell proliferation to soluble antigens and mononucleat

28 Verwilghen J, Vertessen S, Stevens EA, Dequeker J, Ceuppens JL. Depressed T-cell reactivity to recall antigens in rheumatoid arthritis. $\mathcal{F}$ Clin Immunol 1990; 10: 90-8.

29 Pitzails C, Kingsley G, Murphy J, Panayi GS. Abnormal distribution of the helper-inducer and suppressor-inducer T-lymphocyte subsets in the rheumatoid joint. Clin Immunol Immunopathol 1987; 45: 252-8.

30 Morimoto C, Romain PL, Fox DA, Anderson P, Di Maggio $\mathrm{M}$, Levin $\mathrm{H}$, et al. Abnormalities in $\mathrm{CD}_{4} \mathrm{~T}$-lymphocyte $\mathrm{M}$, Levin $\mathrm{H}$, et al. Abnormalities in $\mathrm{CD}_{4} \mathrm{~T}$-lymphocyte subsets in inflammat.

31 Schreiber S, Raedler A, Stenson WF, MacDermott RP. The role of the mucosal immune system in inflammatory bowel disease. Gastroenterol Clin North Am 1992; 21: 451-502.

32 Deutsch K, Reich K. Immunological aspects of inflammatory bowel disease. Endoscopy 1992; 24: 568-77.

33 Kansas GS, Wood GS, Fishwild DM, Engleman EG. Functional characterization of human T-lymphocyte subsets distinguished by monoclonal anti leu-8. F Immunol 1985; 134: 2995-3000.

34 Kanoff ME, Strober W, Fiocchi C, Zeitz M, James SP. CD4 positive leu-8 negative helper-inducer $T$ cells predominate in the human intestinal lamina propria. F Immunol 1988; 141: $3036-41$.

35 Fais S, Pallone F, Squarcia O, Biancone L, Ricci F, Paoluzi P, et al. HLA-DR antigens on colonic epithelial cells in inflammatory bowel disease I. Relation to the state of activation of lamina propria lymphocytes and to the epithelial expression of other surface markers. Clin Exp Immunol 1987; 68: 605-12. 